\title{
Investment in Land Restoration: New Perspectives with Special Reference to Australia
}

\author{
John E. Leake $\mathbb{D}$
}

check for updates

Citation: Leake, J.E. Investment in Land Restoration: New Perspectives with Special Reference to Australia. Land 2021, 10, 156. https://doi.org/ 10.3390/land10020156

Academic Editor: Marta Debolini

Received: 23 December 2020

Accepted: 29 January 2021

Published: 3 February 2021

Publisher's Note: MDPI stays neutral with regard to jurisdictional claims in published maps and institutional affiliations.

Copyright: (C) 2021 by the author. Licensee MDPI, Basel, Switzerland. This article is an open access article distributed under the terms and conditions of the Creative Commons Attribution (CC BY) license (https:// creativecommons.org/licenses/by/ $4.0 /)$.
Faculty of the Professions North Terrace Adelaide, University of Adelaide, Adelaide, SA 5000, Australia; john.leake@adelaide.edu.au

\begin{abstract}
Environmental services of biodiversity, clean water, etc., have been considered byproducts of farming and grazing, but population pressures and a move from rural to peri-urban areas are changing land use practices, reducing these services and increasing land degradation. A range of ecosystem markets have been reversing this damage, but these are not widely institutionalized, so land managers do not see them as "real" in the way they do for traditional food and fiber products. There are difficulties defining and monitoring non-food/fiber ecosystem services so they can be reliably marketed, and those markets that do operate usually do so in a piecemeal single product way in the interest of simplicity for the buyer, and seldom adequately regulate or compensate land managers for non-market benefits. New profitable uses of degraded water and regenerating land are emerging, but they require technology transfer or supply chain development to facilitate adoption. There is a need for a transformational change in the way land and water are used to promote a broader approach, so environmental services become a mainstream activity for land managers. A farsighted Philanthropist is required to support an International institution to take up the challenge of institutionalizing such a 'brokerage' system to operate globally.
\end{abstract}

Keywords: ecosystem services; biodiversity; salinity; carbon-sequestration; ecosystem-servicemarkets; transformational change; community based NRM organizations; regenerative agriculture; UNCCD; World Bank

\section{Introduction}

\subsection{Background and Context}

Farming has traditionally been an individual, family or corporate endeavor aimed at profit or food production. It is also increasingly seen as providing important environmental services such as biodiversity, the production of clean water, carbon sequestration, etc., although the methods of incentivizing the farmer for the production or protecting of these are still evolving. Environmental services are a subset of the sum of benefits obtained from nature termed ecosystems services, in turn categorized in four classes, viz., provisional, regulating, cultural and supporting [1,2]. Supporting and regulating services are those services crucial for the sustained supply of provisioning services and cultural services, as depicted in Figure 1. Supporting and regulating services are often replaced by external human inputs (mineral fertilizer to replace natural nutrient cycling, pesticides to replace natural pest control) in intensively managed agricultural landscapes, resulting in a disconnection between supporting and regulating services on the one hand and provisioning services on the other. However, for the less intensive and for low-income farmers with limited resources, these supporting and regulating services may not be sufficiently replaced and become crucial for provisioning services, leading to degradation. 


\section{Ecosystem services}

\begin{tabular}{|c|c|c|c|}
\hline Provisioning services: & Regulating services: & Cultural services: & Supporting services: \\
\hline $\begin{array}{l}\text { Products obtained from } \\
\text { ecosystems. }\end{array}$ & Regulate ecosystem processes. & $\begin{array}{l}\text { Non-material benefits obtained } \\
\text { from ecosystems. }\end{array}$ & $\begin{array}{l}\text { Necessary for production of all } \\
\text { other ecosystem services }\end{array}$ \\
\hline $\begin{array}{l}\text { Including: } \\
\text { - Food } \\
\text { - Fibre } \\
\text { - Fuel } \\
\text { - Genetic resources } \\
\text { - Biochemicals, natural } \\
\text { medicines \& pharmaceuticals } \\
\text { - Ornamental resources } \\
\text { - Fresh water. }\end{array}$ & $\begin{array}{l}\quad \text { Induding: } \\
\text { - Nr quality regulation } \\
\text { - Climate regulation } \\
\text { - Water regulation } \\
\text { - Erosion regulation } \\
\text { - Water purification \& } \\
\text { waste treatment } \\
\text { - Disease regulation } \\
\text { - Pest regulation } \\
\text { - Pollination } \\
\text { - Natural hazard regulation. }\end{array}$ & \begin{tabular}{l}
\multicolumn{1}{c}{ Including: } \\
- Cultural diversity \\
- Spiritual \& religous values \\
- Knowledge sytems \\
- Education values \\
- Inspiration \\
- Aesthetic values \\
- Social relations \\
- Sense of place \\
- Cultural heritage values \\
- Recreation \& eco-tourism.
\end{tabular} & $\begin{array}{l}\text { Including: } \\
\text { - Soil formation } \\
\text { - Photosynthesis } \\
\text { - Primary production } \\
\text { - Nutrient cyeling } \\
\text { - Water cycling. }\end{array}$ \\
\hline
\end{tabular}

Figure 1. A typology of possible ecosystem services, including those of the products of direct interest to farmers and other land managers [3].

Population pressure and changed land use have seen much formerly productive land and water become degraded. Where the land manager or farmer can re-establish sustainable production of marketable goods, it might be expected to be funded in the ordinary course of the farming business, but this becomes more difficult when the damage is relatively intractable, such as salinity, acidity, and erosion (see below). In these situations, most of the benefits are substantially not marketable, and sometimes the cause originates outside the farm, making compensation for the damage difficult to collect and regulation difficult to implement. A significant class of farmland suffering from this degradation lies in the growing areas of peri-urban land. Feng et al., [4] (this volume), have discussed the impact from the ongoing migration from rural areas to cities and near city farmland using a prefecture in South West China as an example. The resulting flow of polluted storm or other drainage waters from urban to peri-urban and rural areas often contains pollutants such as salts, heavy metals, biologically active chemicals, and nutrients, having attendant health and eutrophication impacts on the rural land it may be draining to. This creates a significant need for restoration that can seldom be paid for by the land manager or farmer of that land.

This damage presents as a continuum between lightly impacted and heavily polluted or damaged sites, sometimes in the same general area depending on topography and drainage. In this commentary, there is a focus on degradation that the land manager can realistically address to restore some production, or to create reserve lands, if provided with supplementary payment or other incentives to offset the additional costs. This paper does not cover areas of gross pollution damage, where the problem is more logically covered by a sewage treatment works. It often uses salinity as representative of the more extreme types of degradation farmers might address from among those that occur, as its treatment illustrates some of the complexity in the issues reviewed (see below).

\subsection{Public Investment in Land Restoration}

Much public sector investment in research and extension has occurred over time to achieve ecological restoration ends; terms such as Sustainable Land Management (SLM) and Climate Smart Agriculture (CSA) as articulated by the Food and Agricultural Organization of the United Nations (FAO) [5], and by the UNCCD as Land Degradation Neutrality (LDN), are being championed by the United Nations Convention to Control Desertification (UNCCD) [6]. The many approaches, termed agroecological approaches for example 'regenerative agriculture' are recorded in successive reports of the High-Level Panel of Experts [7] and are becoming mainstream in development agency literature and plans, but uptake by farmers and other land managers remains low. 
Why is this?

As has been said in different ways by many observers [8], they will not undertake changes in land use unless:

- It is profitable;

- It conforms to a significant extent with their experience and values.

Investments in conservation, restoration and sustainable ecosystems use are increasingly seen as a "win-win situation" that generates substantial ecological, social, and economic benefit, but the distribution of benefits and the apportionment of costs and rewards are not often skewed in favor of the land user. Although these efforts may have been successful in terms of generating environmental benefits, very few provide the range of goods and services once provided by the original ecosystems or even the degraded systems that were replaced [8].

The experience of most land managers and livestock keepers is that damaged land is unprofitable. Land managers have always made efforts to adapt to salinity and other significant damage (farmers do not want to relocate), but these interventions will cease once livelihood problems overwhelm them. Most governments have not seen it as profitable to subsidize the rehabilitation of damaged land, apart from through R\&D and extension, as this requires sustained effort for bio physical success, the scale of investment is high, and the returns are uncertain [5]. There is also a legacy of failure to achieve the expected financial benefits, particularly with salinity, often because plants and techniques have not been well targeted [9], and partly because of inadequacies with the survey and mapping capabilities for the fine grain required for the accurate targeting and apportioning of costs and benefits $[10,11]$. From the perspective of land managers, there are at least three factors inhibiting action:

- The delay between the investment and the benefit stream as new techniques such as perennial halophytes become established or soil or landform treatments take effect;

- Many of the benefits such as biodiversity enhancement, carbon sequestration, etc., are not, or are only partially useful, to the land manager;

- There is often significant technical complexity and/or a need to access new plants for land regeneration, requiring technical assistance and demonstration for success.

\subsection{Linking Research to On-Ground Outcomes}

In 2004, Australia made a substantial investment, eventually totaling some $\$ A U 1.5$ billion in pursuit of "the nation's plan to combat salinity" (House of Representative report 2004) [12]. Following a 10-year National Dryland Salinity Program of research to support this plan, the final report [13] listed lessons for policy makers including:

- Practical solutions are not easy to find and their impact may not be felt for decades;

- Salinity management should be integrated with other natural resource management strategies;

- In some cases, we will have to live with salinity and must find the institutional and practical means to make that possible.

This complexity has not often been well served by research as most of it focuses on a few aspects of landscape management in the interests of limiting the variables [14]. Investment into funding successful results of $R \& D$ that have occurred is also not well served as much practice is dominated by official funding agencies who are reluctant to "own" mechanisms such as reverse tenders and other private sector funding activities, which are perceived as risky [15]. An important component of this risk is price discovery for services previously provided "free". According to Australia's premier research group (CSIRO), the economic value of public benefits such as clean water, climate stability, biodiversity, and soil fertility is clear, and as elaborated in the Global Assessment Report appended totheir website [11]. However, there are few markets where they can be purchased readily, and there are significant ongoing difficulties assuring buyers that the services or goods have beenprovided and are durable for the time expected by the financiers. Some suggest 
many ecosystem services cannot be valued and so traded [16], and many suggest other forms of regulatory or indirect subsidies can be more effective than market systems, which can be distorted through power imbalances (see below), conflicts of interest and access, particularly in less developed nations [17,18].

The persistence of research interest in salinity and other relatively intractable Natural Resources Management (NRM) issues began when future food demands became apparent in the 1950s and is testament to the need, but also the difficulties. This may relate to the reluctance of supporters to deal with each problem in a broader NRM context, precisely due to the technical and, particularly, the institutional and social complexity of implementing the results. In Australia, where experimental activity has been evaluated as successful over a 10-year period, there has been a lack of institutional and political follow through, echoing experience in the US [19].

\section{Implementing Natural Resources Management}

\subsection{Participatory Approaches}

Throughout this period, there has been a move away from the traditional relatively closed economic planning system, in domains where it has become apparent the variables are too complex for administrative certainty, towards more open systems that allow for human differences in "world view" and natural resource systems that vary greatly across short distances and in time [20-22]. These systems delegate more power to local stakeholders and participants who are held to be more likely to understand or to adapt to these differences when they are discovered. Their origin lies in "systems theory" [23], they include "institutional learning" [24], "experiential learning" [25] the impact of "degrees of empowerment" [26] and "resilience and stability of ecological systems" [27]. Together, they facilitate considering the world as a linked system of subsystems, amenable to movement through the action of people. There are many varieties of these essentially adaptive management protocols, often collectively referred to as "participatory approaches", but they remain contested with some traditional planners as the cost and time for implementation remain as uncertain as the outcomes, and they may still not allow for the impact of short project and political cycles [28,29].

\subsection{Australian Experience}

Australia has had a long interest and very substantial investment in participatory approaches to engaging, education and contributing to the financing of natural resources management on-ground with some notable successes. In order of introduction:

- The Landcare movement, which by the mid-1990s was estimated to have reached one third of Australian farms through some 6000 local Landcare groups, has been excellent in raising community awareness of the links between production and the supporting environmental services and in communicating many different solutions, such as 'regenerative agriculture' to farmers, supporting agencies, schools, etc. However, at the end of the "Decade of Landcare", it was judged a failure by the Australian National Audit Office (ANAO) in reducing land and water degradation-its stated objectives asquoted in Campbell 2016 [30]. These were assessed to have been largely aspirational and relying on farmers and land managers to fund changes in land practice by themselves, such as 'regenerative agriculture' which has succeeded in this way.

- The National Heritage Trust (NHT) was formed in 1997 to address this need for investment to support Landcare, and this morphed into a regional NRM model based on regional or catchment organizations under different names in different states. By 2007 and a decade of activity, some \$AU 1 billion had been invested in planning and implementing NRM activities across Australia. Campbell goes on to discuss, from his own experience in establishing Landcare and administering NHT, how an essentially community-based process gradually evolved into a more top-down process under political pressures inherent in changing governments, and state government seeking to 
"cost shift" by assigning state officials to manage these activities and then selling down their own research farms and regional centers. The resulting competition for staff and resources and support for funding diminished its initial impact in empowering land managers to implement activities they saw as being in their interests, even where subsidized [30]. See also Lockwood et al. who discussed "Multi-level Environmental Governance: lessons from Australian natural resource management" [31].

- This author's experience with the latter program (2005-2014) showed that significant on-ground impacts are achieved where strong local boards relate well with regional councils, state authorities and innovative commercial service providers to create "nested multi-level systems of community-based governance", as described by Marshall $[32,33]$, but this was very much personality driven and against the trend towards centralization discussed by Campbell and others. An important feature of the successes was the ability of strong boards to align the community's strategic plans and timing with the sometimes slightly different strategic objectives and timing of funding bodies—state, private and philanthropic - as part of a "brokerage" function. This tended to, but did not finally, overcome the inherent weakness of the electoral process in being able to follow a transformational process long enough for it to be institutionalized and to facilitate the mobilization of additional resources from different sources.

\subsection{International Experience}

International experience with participatory approaches has a similarly long history and very significant investment since the 1990s, where differences across world views and their interaction with landscapes are often wider than in Australia and other Organization for Economic Cooperation and Development (OECD) nations, but remains contested for similar reasons. This requires more and more flexible approaches but is justified by the increasing scale of the population movement induced problems, as discussed by Sinclair and Coe [34]. Each of the main international finance institutions, many national development agencies and private Non-Government Organizations (NGO)s pay attention to these approaches in providing finance for community and environmental related "development", as discussed below, but many focus on a particular intended outcome, such as "biodiversity" conservation or "poverty alleviation", which can be confusing to land managers whose world views may not see such divisions or see them in similar terms. A more significant issue in scaling up or investing across scales for natural resource related activities is the necessity to nest them within national strategies, laws and changing political imperatives if they are to be implementable, as discussed by the World Bank's responsible officer for Community Driven Development (CDD) [35]. Interested private philanthropic or commercial firms seeking a "social license to operate" have similar hurdles, and the communities themselves need a way utilize these potential assets towards their own objectives in some continuing way.

\section{Sources of Finance for On-Ground Outcomes}

The growth of tenders for the supply of biodiversity conservation (conservation tenders) in lower income countries has been rapid, and successful in large trials, but a lack of local markets for conservation and design difficulties have limited replication, even though it is seen to contribute to poverty alleviation [36]. These authors conclude that auction systems designed to deliver income transfer outcomes are more directly attractive to farmers than limited technical issue auctions that have high transaction costs in delivery. Others suggest taking a "landscape approach" to implementation, to take the range of land users and ecological, social, and institutional circumstances into better account as being more successful [37].

Significant international grant investments have long been directed towards more integrated and open-ended approaches to land degradation by international agencies such as the World Bank [38], but these tend to have a poverty alleviation focus. These investment 
packages have evolved as new ecosystem considerations become significant, such carbon sequestration [39]. The Climate Smart Territories (CST) program, for example, seeks to integrate adaptation to climate change with the need for food security [40]. Specific Payments for Ecosystems Services (PES) are increasingly described in these programs, although the "payments" by the regional, national or global beneficiaries are only implied as they are covered in the institutional grants or loans.

In these examples, PES is seen in a broader sense, contributing to the livelihood of land managers and to other off site, regional or international beneficiaries, but replication is still limited, the transaction costs are significant. NRM in this broad sense is also not sustainable once the institution withdraws support for the transaction costs [4]. These substantial but still piece meal investments will not solve the issue of sustainability. Non-market investment in NRM will only be sustainable once land managers learn they can depend on payments for the ecosystem benefits they deliver and that these payments will need to be seen to come from the beneficiaries one way or another. This means "bridging the gap" from beneficiaries to the land manager, upon whose agency delivery depends.

There is no consolidated figure for international investment in natural resources management and there are many guises: rural development, agriculture, food security catchment management, irrigation, etc. The scale and range of funds available for directed NRM are already very considerable and growing (although still modest compared with the investment in industrial production practices, which operate within markets). For example, for biodiversity conservation alone, 183 funds were listed by the Aichi Convention Secretariat [41] for 2006. The private sector also invests in various ways for conservation, usually related to gaining "a social license to operate" (SOL). There also many private philanthropic and Non-Government (NGO) investments in carbon sequestration or forestry, but all of these are discrete "markets" usually operating individually and without a broader view of their landscape and human impact.

This suggests that the funding need is not so much for new innovative funding mechanisms, but towards thinking "innovation" more broadly [42]. Are we ready for a transformational change in Natural Resource Management that sees land mangers as sellers of a range of desired services for prices that will induce the action? The transaction costs will be significant, but only worth making if the result is a self-sustaining market made up of willing buyers and sellers. In short, a system to assure both on performance, and to facilitate persistence for longer than the normal investment project cycle of 4-7 years.

Transformational change is common in business, but in the world of public policy, many reforms fail for various reasons including gaining and sustaining support for change, so political leaders often settle for incremental change even if they recognize transformational change is needed $[14,43]$. What has changed that might justify a new approach?

\section{Towards Transformational Change in NRM Funding}

There is now a growing awareness, particularly among electorates and populations in many political systems, that we have (or soon will) cross global thresholds having significant risks for this and future generations. Scientific opinion suggests that we have already transgressed two of nine planetary boundaries upon which life depends: risk of climate change and biodiversity loss [44]. "Think global and act local" has entered the popular lexicon, but how to achieve this is less clear. The paradigms of the Economics of the Coming Spaceship Earth as articulated by Boulding in 1966 [45] and the 1974 Gaia concept of Lovelock and Margulis [46] are being revisited; to change our conception of causality from state change - to process change, away from an idea of local causality-to a global system that operates across scales and knowledge domains [47]. The "biodiversity" and "climate" emergencies are often treated separately, although from a landscape perspective they are closely related. Soil changes are very significant to both, so we address these needs through the (slightly) more topical climate issue, and soils.

The impetus of "climate emergency" gave rise to recommendations at the Conference of Parties (COP) 24 at Katowice in Poland in 2018 that "ambitious mitigation actions are 
indispensable to limit global warming to $1.5^{\circ} \mathrm{C}$." and "a mix of mitigation and adaptation implemented in a participatory and integrated manner can enable rapid, systematic transition in urban and rural areas" with significant new investment, and it is the depleted (degraded) soils where the greatest potential for carbon gains exists, at least back to a suggested "steady state" (Box 4.1 IPCC Working Group III) [48]. The IPCC Working Group III's 5th assessment in 2014 identified that at USD 100 per/ton $\left(\mathrm{CO}_{2} \mathrm{eq}\right)$, the restoration of organic content in soils has the greatest potential for considerable significant sequestration to occur in land-based systems and that the equivalent value for grazing management is \$US 20 per/ton $\left(\mathrm{CO}_{2}\right.$ eq.). It was suggested in Paris in 2015 that at this scale of investment, a "one shot" significant contribution to climate stability is possible that will also enhance food security and biodiversity while reducing poverty, in different ways in different regions [49]. The key is to turn this investment into a sustainable new system. The Paris Accords suggest that an appetite for a global effort exists, but for this to occur institutional innovation and a broader definition of PES is required to address these scale issues and to communicate this broader way of viewing NRM to the international and national institutions who will need to support the investments required for a sustained change.

However, as noted above, financing "think global—act local" activities in a practical way across these scales requires a transformation in thinking about NRM. This will entail the articulation of a compelling narrative for change and the sustained support of international "champions" for long enough for the transformation to occur [43]. There are related calls for a transformational change in agriculture to meet food and poverty alleviation needs, and also to address conflicts between some agricultural practices and biodiversity loss, including in soils $[7,34,47]$.

\subsection{Matching Costs and Benefits Across Scales}

The concept of Payments for Ecosystem Services may be a good organizing principle in developing an understandable narrative (Figure 1). Seen in this way, the incentives can also encourage land managers to produce services only peripherally related to their primary purpose of production. Each of these services has different specialized markets not readily accessed by farmers, and which require specialized systems for monitoring and assurance.

These can be divided into:

1. Services of direct marketable or consumption value to the resident land manager, (and recipients) usually only the Provisioning Services of food, or fuel products, but sometimes there are cultural or aesthetic benefits from repairing unsightly land.

2. Services which overlap with some Regulating and Supporting Services that, according to FAO, accrue at other scales as Positive Externalities [50]. For example, increasing organic activity through land regeneration improves soils in various ways to the benefit of the farmer, but also sequesters carbon of benefit at the global scale by mitigating climate change. There are many other possible actions such as vegetation changes that provide farm scale benefits by reducing salt impacts on growth but also impact on regional groundwater and biodiversity, both of value off site.

3. Services that may have insufficient value to the farmer to motivate action but are of value to urban and externally based funding sources seeking regional, national, or global benefits. Capturing these positive externalities requires appropriate action by farmers, but quoting Lefroy et al. [51], success "will depend on the extent to which we can adapt land use systems to meet the needs at (different) scales without compromising their profitability". This has been described in Australia as "bridging the urban-rural divide" [52]. These latter two classes of services illustrate the concept of "the "flow" of ecosystem services from providers to the recipient(s) across temporal and spatial scales and mapping these as a tool to enable projecting alternative uses for different purposes [11]. 
Incentives for land managers to provide PES as additional benefits may be either financial as above or non-financial in the form of regulations or enabling changes in land use, or taxation relief, all of which are already provided in some circumstances.

Australia has a leading reputation in developing integrated NRM institutions (as [53] discussed above), also called Community Based Natural Resource Management (CBNRM), but has not really bridged this divide, except when the government stands behind the payments [19], and there is a tendency for a centralization of control of these processes where it does $[30,31]$. There are different examples in different states and different names such as the Natural Resources or Catchment Management Boards [54,55]. These boards act for land managers to formulate long term strategic plans and monitor the implementation of annual operational plans as an adaptive management system. They also align these strategic objectives with those of external funds acceptable to the funding bodies. However, they have not yet become self-sustaining as they are not sufficiently engaged in real markets, and governments are reluctant to support activities that they have less control over, such as reverse tenders [19]. There are officially supported private investment vehicles to address this complexity, including by access to non-financial incentives, for example, for setting aside lands as reserves as discussed by [56], but they are not yet mainstream.

\subsection{New Developments in PES Markets}

However, this may be changing as the links between soil carbon (organic matter) and soil health, structure, water holding capacity and so productivity are well established in mainstream agriculture and have been recently established for saline lands [57], and specialist carbon merchants are emerging that are willing to operate at the farm and regional level. Although guaranteed carbon offset markets are still much lower than the Paris Accords hope for, markets are moving. Many emerging carbon offset merchants and key buyers are prepared to negotiate much higher prices in the voluntary market. In 2020, prices ranged from \$US 0.40 cents for certified emissions, \$US 18 for Sky UK Ltd, \$US 7.50 average of voluntary tree-planting offsets and \$US 18 median internal carbon price, against \$US 30 for the World Bank's social cost of carbon, and some internal prices of \$US 44 and $\$$ US 156, as reported by Tucker [58]. The buyers act responsibly at these high prices, and the merchants similarly, because they see the potential size of the market once markets move in line with the costs and benefits as proposed under the Paris round.

According to Petrokofsky et al. [59], the development of markets for carbon sequestration has been limited due to a lack of a cost-effective monitoring and assurance systems, but improvements in remote sensing/ground survey systems and the International Governmental Panel on Climate Change (IPPCC) proposed higher prices for carbon give encouragement that systems will be agreed under increased pressure to address climate change. As Issa et al. say [60], accommodating an open-ended employment of technology, objectives, funding sources and adaptive management is costly but arguably essential considering the importance of the global imperatives of the linked objectives.

\subsection{Towards a Brokerage Service for Technology and Finance}

There is a requirement for an internationally respected entity to "broker" funds and expertise for different purposes and from different sources: international, national, private, non-government and philanthropic. There are substantial international agencies with the capacity to perform this service in most countries and possessing detailed methodologies that might be utilized in this way (see below in Section 5). Feng et al. [4] have developed an index of ecosystem services to enable investments to be ranked according to global, national, catchment or local level. This facilitates the "brokering" and monitoring of services [61] by land managers to markets interested in specific ecosystem outcomes at these different scales. Five distinct land uses were agreed on for the studied area of Qinzhou prefecture in Southern China and the services from near natural land uses, grazing land and woodland/forest land had significant benefits at the catchment level, while tree and 
shrub areas had higher global benefits derived from biodiversity and carbon sequestration outcomes, as depicted in Figure 2.

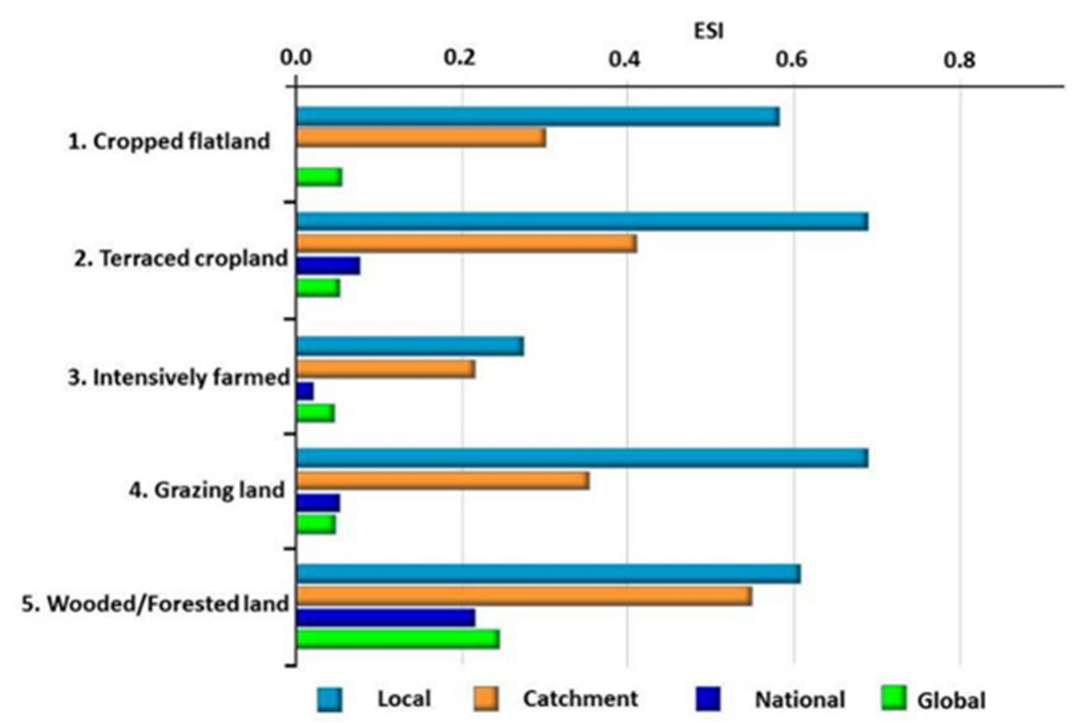

Figure 2. Ecosystem service index (ESI) for the five major land use types in rural and peri-urban areas ranked according to the contribution at global, national, catchment and local levels [4].

Such an index can be visualized as a local landscape mapping tool within the "stocklow" system proposed by Paggella and Sinclair for trading at other scales and quantifying the flow of ecosystem services from providers to recipients, "closing the gap" [11].

Implementing a system to broker services in this way will require a consensus on suitable institutional arrangements and a significant investment while buyers and service providers gain experience and trust for long-term sustainability.

\subsection{Other Income Earning Opportunities}

Most farms considered herein have evolved to produce traditional food and fiber products, but closer settlement and the growth of urbanization have created demand for specialty products, and/or the existence of unconventional resources creates other opportunities-some already commercial, some in commercial development. Some of these are related to new uses for second class water, for example, for substituting these waters for potable waters that may now be used for this with the benefit coming from the value of the potable water saved. Some may come from stripping nutrients from saline effluent streams, resulting in, for example, a reduction in pollution from irrigation, food processing, and intensive horticultural production $[62,63]$. Income here may come from payments by these processors to avoid penalties from discharging such effluents to water ways. The technology for blending saline wastes economically and safely with better quality water to augment supplies has been developed and evaluated in several centers, for example, International Center for Bio-saline Agriculture (ICBA) in the UAE [64], and different plants have been developed for amenity use such as turfs [65]. The reuse of saline effluent water, including on amenity areas, has its attendant risks but these can be guarded against [66]. Technologies such as Biochar utilizing biomass wastes for energy generation and soil amendments are significant in some regions [67].

There are well developed "markets" to set aside land, e.g., as biodiversity or cultural reserves that can add to the return for "rezoning" degraded lands for new uses [56].

There is a range of attractive specialty investments as explained by Panta et al. [68], for example, to utilize the enormous and growing supply of saline water that could be opportunistically offered through such a broker service. Examples include direct energy generation from salinity gradients [69], irrigation of plants for bio energy, as suggested by IPCC WG1 [70], saltwater-based food production systems [71], inland aquaculture, 
associated constructed wetlands [72], and others such as payments for avoided pollution from saline effluents [63]. Each of these have carbon market implications. Recent advances in processing halophyte biomass into a human grade protein are explained by [73].

Enabling land managers to investigate and take advantage of these types of opportunities requires technical support and market innovation for success. This is not normally achievable by land managers acting alone.

\section{Examples of Institutional Arrangements that Have Addressed Technical and Social Complexity}

Some Australian examples of institutions, such as Landcare, aimed at facilitating land managers to address NRM complexity have been discussed above. An international example is the Community Driven Development (CDD) approach [74]. These began in their modern form in about 2004 (WB 2004) with a poverty alleviation focus, but really built on experience since the 1990s by many national development agencies, NGOs and the different United Nations (UN) development agencies (Leake 2000) [75]. CDD approaches have been employed successfully to institutionalize planning and management skills by several multi-lateral funding bodies: World Bank, Asian Development Bank, and the International Fund for Agricultural Development (IFAD), and versions by many national development financiers. Under this strategy, successive grant funds are provided if community elected stakeholders can prepare, implement and report adequately on development activities of their choice, with agreed funding objectives, based on the best available science [74]. The primary purpose of these systems is to introduce or re-introduce accountable local government, and they achieve local commitment by addressing livelihood issues, food production, etc., under procedures agreed with the financiers [75]. The scale of these activities is considerable, for example, the World Bank reports "As of fiscal year (FY) 2018, there are 199 active CDD projects in 78 countries totaling $\$ 19.7$ billion. CDD approaches are particularly prominent in conflict and fragile situations-CDD programs operate in 22 countries on the list of fragile and conflict-affected states, and an additional seven countries with internally displaced populations, refugees, or conflict zones." Other related systems have specific objectives and appetites for risk, e.g., education grants, conservation, R\&D, etc. Many large bilateral donors also sponsor funds to support socially complex action, usually region specific, and are known to have different appetites for risk.

The recent announcement of USD 14 billion to the UNCCD sponsored Great Green Wall Fund by the World Bank and others is a further indication of increased interest in NRM linking biodiversity to climate adaptation and mitigation and food security, although it is not clear if this will take the broader approach suggested herein (source) [76].

The private sector, particularly mining companies and others operate funds either related to some other investment in the area, or generally for Social License to Operate (SLO) reasons. Some, such as the Global Environmental Facility (GEF) [77], provide grant funds as incentives for other investors to modify their plans to achieve certain ecosystem outcomes. Different stakeholders, such as indigenous people, are particularly relevant for many remote areas [78]. The UN recently recognized that indigenous people are best at conserving biodiversity when they have secure resource use rights [14] (recommendation D2 in the Intergovernmental Platform for Biodiversity and Ecosystem Services (IPBES) appendix).

Carbon markets are developing to enable emitters of $\mathrm{CO}_{2}$ to purchase sequestered carbon to offset their own emissions. The Paris climate targets and reinforcement at COP 24 at Katowice in Poland mean that markets to promote climate mitigation have recommenced growth after a significant beginning in the decade following 1997 [79]. This potential has become clearer and more politically practical as the scale of carbon sequestration needs world-wide is better known, and an understanding of the enormous potential gains to be made in dryland areas has become better appreciated [80].

Although the CDD system has its critics, these mainly focus on the degree of success, particularly in targeting, that has been claimed by its proponents rather than any fundamental flaw [81]. These critics do point to a perennial problem with development assistance, 
including with NRM, that the programs and ideas do not persist once the agency support is withdrawn, unless they are supported long enough to be institutionalized $[49,82]$.

\section{Conclusions}

The rapid movement of people from rural to urban areas increases the pressure on rural areas to produce more food and fiber, for which conventional supply chains and financing already function quite well. This movement also creates an even greater demand for the ecosystem services on which our lives depend, and as both the ratio of urban/rural land and the absolute number of people have increased, these markets do not function well.

World markets are unaccustomed to serving these ecosystem services demands, they are difficult to "package" as tradable products, land managers have little experience selling them and regulatory incentives do not persist if land managers do not see their livelihoods to have benefited. However, there is evident demand based on the significant experimental investments that have been made in both developing and many OECD countries over recent decades.

The marketing task is made even more difficult because most of the beneficiaries of these services are located far from the providers, at the catchment, bioregion, national or global levels, and the global flow of ecosystem services that benefits all is not well understood. Even some significant NRM programs, such as in Australia for over 10 years or more, have not become institutionalized or internalized by land managers as a mainstream activity.

There is some recognition of a need for a "transformation" in the way ecosystem services are funded if these suppliers and "buyers" are to meet in a sustainable way to "bridge the gap" across these scales, but there is less appreciation of the time it takes for a new paradigm to become institutionalized.

This commentary adds to the literature on NRM systems by suggesting that the community driven development approach might be adapted to establish a technical, marketing "brokerage" service, and that the International Finance Institutions have the resources, mandate, and potential time frame to see the transformation through until enough land managers come to see the new markets "as reliable".

However such a change in international approach is a new 'paradigm', away from the management approach adopted post WWII, to a global brokered 'market of ideas and value' crossing scales, local and national to Global, and this will require the support of a Philanthropist for one or more international finance institutions (IFIs), such as the World Bank or development institutions, such as the United Nations Convention to Combat Desertification (UNCCD) to take up the challenge for long enough for it to be institutionalized as a new global market.

Funding: This paper was funded by the Institute for International Development Fund as a 'pro bono' activity http:/ / www.iid.org/publishing.html.

Institutional Review Board Statement: Not applicable.

Informed Consent Statement: Not applicable.

Data Availability Statement: Not applicable.

Acknowledgments: The text was reviewed by University of Adelaide GFAR personnel Mike Young https://researchers.adelaide.edu.au/profile/mike.young.

Conflicts of Interest: There is no conflict of interest. 


\section{References}

1. De Groot, R.S.; Alkemade, R.; Braat, L.; Hein, L.; Willemen, L. Challenges in Integrating the Concept of Ecosystem Services and Values in Landscape Planning, Management and Decision Making. In Ecological Complexity 7; Elsevier: Amsterdam, The Netherlands, 2010; pp. 260-272.

2. Squires, V. Ecological Restoration: Global Challenges, Social Aspects and environmental Benefits: An Overview, chapter 1. In Ecological Restoration: Global Challenges, Social Aspects and Environmental Benefits; Squires, V.R., Ed.; Nova Science Publishers: Hauppauge, NY, USA, 2016.

3. De Groot, R.S.; Wilson, M.A.; Boumans, J.A. Typology for the Classification, Description and Valuation of Ecosystem Functions, Goods and Services. Ecol. Econ. 2002, 41,393-408. [CrossRef]

4. Feng, H.; Squires, V.R.; Wu, J. Linkages between ecosystem services provisioning, urban growth, and the rural-urban interface: A case study from China. Land 2020, 10. in press.

5. FAO. Sustainable Land Management. Available online: http://www.fao.org/land-water/land/sustainable-land-management/ slm-practices/en/ (accessed on 2 February 2021).

6. UNCCD. Scientific Conceptual Framework for Land Degradation Neutrality 2017. Available online: https://www.unccd.int/ sites/de-fault/files/documents/2019-06/LDN_CF_report_web-english.pdf (accessed on 16 January 2021).

7. HLPE. Agroecological and Other Innovation Approaches for Sustainable Agriculture and Food Systems that Enhance Food Security and Nutrition Report 14 2019. Available online: http:/ / www.fao.org/3/ca5602en/ca5602en.pdf (accessed on 4 January 2021).

8. Squires, V.R. Rangeland Stewardship in Central Asia: Balancing Improved Livelihoods, Biodiversity Conservation and Land Protection; Springer Science \& Business: Berlin/Heidelberg, Germany, 2012. [CrossRef]

9. Cork, S.; Eadie, L.; Mele, P.; Price, R.; Yule, D. The Relationship between Land Management Practices and Soil Condition and the Quality of Ecosystem Services Delivered from Agricultural Land in Australia. Kiri-Ganai Research Commissioned Report for the Australian Government's Caring for Our Country Initiative. 2012. Available online: https:// kiriganaicom.files.word-press.com/ 2016/09/soils-final-report-full.pdf (accessed on 23 June 2020).

10. Bennett, S.J.; Barrett-Lennard, E.G.; Colmer, T.D. Salinity and Waterlogging as constraints to saltland pasture production: A review. Agric. Ecosyst. Environ. 2009, 129, 349-360. [CrossRef]

11. Paggella, T.; Sinclair, F. Development and use of a typology of mapping tools to assess their fitness for supporting management of ecosystem service provision. Landsc. Ecol. 2014, 29, 383-399. [CrossRef]

12. House of Representative Report. The Nation's Program to Combat Salinity. Australian House of Representative Standing Committee Report, Chapter 2. 2004. Available online: https:/ / www.aph.gov.au/Help/Federated_Search_Re-sults?q=aphref.aph. gov.au_house_committee_scin_salinity_report_chapter2.pdf\&ps=10\&pg=1 (accessed on 9 October 2020).

13. Van Buren, M.; Price, R.J. Breaking Ground-Key Findings from 10 Years of Australia's National Dryland Salinity Program Land E Water Australia; National Dryland Salinity Program: Canberra, Australia, 2004; ISBN 1920860207.

14. Salzman, J. The Collision of Aspiration and Reality in Payments for Ecosystem Services, chapter 10. In Transformational Change in Environmental and Natural Resource Management, A Guide to Policy Excellence; Young, M., Esau, C., Eds.; Earthscan from Routledge: London, UK; New York, NY, USA, 2016.

15. CSIRO and the IBES Global Assessment Report Appended. Available online: https:/ / ecos.csiro.au/why-we-need-biodiversityfor-life-on-our-planet/?utm_source=ECOS-2020-10\&utm_medium=newsletter\&utm_campaign=ECOS (accessed on 2 November 2020).

16. Small, N.; Munday, M.; Durance, I. The challenge of valuing ecosystem services that have no material benefits. Glob. Environ. Chang. 2017, 44, 57-67. [CrossRef]

17. Leach, M.; Mearns, R.; Scoones, I. Environmental Entitlements: Dynamics and Institutions in Community-Based Natural Resources Management. World Dev. 1999, 27, 225-247. [CrossRef]

18. Chomba, S.; Nathan, I.; Minag, P.; Sinclair, F. Illusions of Empowerment? Questioning policy and practice of Community forestry in Kenya. Ecol. Soc. 2015, 20. [CrossRef]

19. Rolfe, J.; Whitten, S.; Windle, J. The Australian experience in using tenders for conservation. Land Use Policy 2017, 63, 611-620. [CrossRef]

20. Chambers, R. Managing Rural Development, Ideas and Experience from East Africa; Scandinavian Institute for African Studies: Uppsala, Sweden, 1974.

21. Korten, D.E. Getting to the 21st Century, Voluntary Action and Thew Global Agenda; Kumarian Press: Sterling, VA, SA, 1990; Available online: https: / / doi.org/10.1002/pad.4230110609 (accessed on 16 January 2021).

22. Scoones, I.; Thompson, J. Beyond Farmer First, Rural People's Knowledge, Agricultural Research and Extension Practice; Intermediate Publications: London, UK, 1994.

23. Von Bertalaffy, L. An outline of General Systems Theory. Br. J. Philos. 1950, 1, 134-165. [CrossRef]

24. Argyris, C.; Schon, D. Organizational Learning: A Theory of Action Perspective; Addison Wesley Reading: Boston, MA, USA, 1978.

25. Kolb, D. Experiential Learning: Experience as the Source of Learning and Development; Prentice Hall: London, UK, 1984.

26. Arnstein, S. Ladder of Citizen Participation. J. Am. Inst. Planners 1969, 35, 216-224. [CrossRef]

27. Holling, C. Resilience and Stability of Ecological Systems. Annu. Rev. Ecol. Syst. 1973, 4, 1-23. [CrossRef] 
28. Dollar, D.; Pritchard, L. Assessing Aid What Works What Doesn't and Why; Oxford University for the World Bank. 1998. Available online: http://documents1.worldbank.org/curated/en/612481468764422935/pdf/multi-page.pdf (accessed on 2 February 2021).

29. Kanbur, R.; Lustig, N. Why Inequality Is Back on the Agenda; Working Paper 99-14; Cornell University: Ithaca, NY, USA, 1999; Available online: http://publications.dyson.cornell.edu/research/researchpdf/wp/1999/Cornell_Dyson_wp9914.pdf (accessed on 2 February 2021).

30. Campbell, A. Two Steps Forward, One step Back. The ongoing failure to capture synergies in natural resource management (Australia). In Transformational Change in Environmental and Natural Resource Management Guidelines for Policy Excellence, Earthscan studies in Natural Resource Management; Young, M., Esau, C., Eds.; Routlege: Abingdon, UK, 2016.

31. Lockwood, M.; Davidson, J.; Curtis, A.; Stratford, E.; Griffith, R. Multi-level Environmental Governance: Lessons from Australian natural resource management. Aust. Geogr. 2009, 40, 169-186. [CrossRef]

32. Leake, J. Was Involved in this NRM Process in 2 States of Australia Intermittently over 10 Years, Either as a Consultant Environmental Auditor Reporting to a State Natural Resources Commission, or as a Member of a State Natural Resource Council Responsible for All the State's NRM Legislation (2005-2014). Available online: https:/ /researchers.adelaide.edu.au/profile/john. leake\#professional-activities (accessed on 2 February 2021).

33. Marshall, G. Community-based Regional Delivery of Natural Resource Management: Building Systems-Wide Capacities to Motivate Voluntary Farmer Adoption of Conservation Practices, Publication No 08/175; RIRDC: Canberra, Australia, 2008.

34. Sinclair, F.; Coe, R. The Options by Context Approach: A Paradigm Shift in Agronomy Experimental Agriculture; Cambridge University Press: Cambridge, UK, 2019; Volume 55, pp. 1-13. [CrossRef]

35. Wong, S.; Guggenheim, S. Community Driven Development. Myths and Realities; Policy Research Working Paper 8435, Social, Urban, Rural and Resilience Global Practice; World Bank Group: Washington, DC, USA, 2018; Available online: https:/ / openknowledge. worldbank.org/handle/10986/29841 (accessed on 16 January 2021).

36. Wunscher, T.; Wunder, S. Conservation tenders in low-income countries: Opportunities and challenges. Land Use Policy 2017, 63, 672-678. [CrossRef]

37. Scherr, S.L.; Shames, S.; Friedman, R. From climate-smart agriculture to climates-smart landscapes. Agric. Food Secur. $2012,1,12$. [CrossRef]

38. Lutz, E.; Binswanger, H.P.; Hazell, P.; McCalla, A. Agriculture and the Environment. A World Bank Symposium; World Bank: Washington, DC, USA, 1998; ISBN 0-8213-4249-5.

39. World Bank. Carbon Sequestration in Agricultural Soils; Economic and Sector Work. Report no. 67395-GLB; World Bank: Washington, DC, USA, 2012.

40. Louman, B.; Campos-Arce, J.J.; Mercado, L.; Imbach, P.; Bouroncle, C.; Finegan, B.; Padilla, B. Climate Smart Territories (CST) An integrated approach to food security, ecosystems services, and climate change in rural Areas. In Climate Smart Landscapes: Multifunctionality in Practice; Minang, P.A., van Noordwijk, M., Freeman, O.E., Mbow, C., de Leeuw, J., Catacutan, D., Eds.; World Agroforestry Centre ICRAF: Nairobi, Kenya, 2015.

41. UNEP. Catalogue of Funding Sources, Secretariat on Biological Diversity. 2006. Available online: https://www.cbd.int/doc/ guidelines / fin-sources.pdf (accessed on 2 February 2021).

42. Berghöfer, A.; Emerton, L.; Moreno Diaz, A.; Rode, J.; Schröter-Schlaack, C.; Wittmer, H.; van Zyl, H. Sustainable Financing for Biodiversity Conservation-A Review of Experiences in German Development Cooperation; Helmholtz-Zentrum fur Umwelforschung Gmbh-UFZ Permoserstr: Leipzig, Germany, 2017; ISBN 1436-140X.

43. Young, M.D. Transformational Change: In search of Excellence. In Transformational Change in Environmental and Natural Resource Management: Guidelines for Policy Excellence. Earthscan Studies in Natural Resource Management; Young, M.D., Esau, C., Eds.; Routledge: Abingdon, UK, 2017.

44. Rockstrom, J.W.; Steffen, K.; Noone, A.; Persson, F.S.; Chapin, E., III; Lambin, T.M.; Lenton, M.; Scheffer, C.; Folke, H.; Schellnhuber, B.; et al. Planetary Boundaries: Exploring the Safe Operating Space for Humanity. Ecol. Soc. 2009, 14, 32. [CrossRef]

45. Boulding, K. The Coming Spaceship Earth: Environmental Quality in a Growing Economy; Jarrett, H., Ed.; Resources for the Future; Johns Hopkins University Press: Baltimore, MD, USA, 1966; pp. 3-14.

46. Lovelock, J.E.; Margulis, L. Atmospheric homeostasis by and for the biosphere: The Gaia hypothesis. Series Stockholm: International Meteorological Institute. Tellus 1974, 26, 2-10. [CrossRef]

47. Chavalarias, D. From inert matter to the global society, Life as multi-level networks of processes. Phil. Trans. R. Soc. B 2020, 375, 20190329. [CrossRef] [PubMed]

48. Watson, R.T.; Noble, I.R.; Bolin, B.; Ravindranath, N.H.; Verardo, D.J.; Dokken, D.J. Special report on LULUCF. In Technological and Economic Potential of Options to Enhance Mitigation IPCC; Working Group III: Mitigation Chapter 4; Cambridge University Press: Cambridge, UK, 2001; Available online: https:/ /www.ipcc.ch/report/land-use-land-use-change-and-forestry/ (accessed on 2 February 2021).

49. Leake, J. Land Degradation, Biodiversity and Productivity: Pressing Issues in Management of the World's Drylands—A Synthesis. Concluding, chapter 17. In Drylands: Biodiversity, Management, and Conservation; Squires, R., Guar, M., Eds.; Nova Science Publishers: Hauppauge, NY, USA, 2019; ISBN 978-1-1-53615-8096-0651.

50. FAO. Ecosystem Services; FAO: Rome, Italy; Available online: http://www.fao.org/3/a-ar584e.pdf (accessed on 1 November 2020). 
51. Lefroy, E.C.; Flugge, F.; Avery, A.; Hume, I. Potential of Current perennial plant-based farming systems to deliver salinity management outcomes and improve prospects for native biodiversity: A review. Aust. J. Exp. Agric. 2005, 45, 1357-1367. [CrossRef]

52. Bond, A.J.; Saison, C.L.A.; Lawley, V.R.; O'Connor, P.J. Bridging the Urban-Rural Divide between Ecosystem Service Suppliers and Beneficiaries: Using a Distributed Community Nursery to Support Rural Revegetation. Environ. Manag. 2019, 64, 166-177. [CrossRef] [PubMed]

53. Dale, A.; Vella, K.; Ryan, S.; Broderick, K.; Hill, R.; Potts, R.; Brewer, T. Governing Community-based Natural Resources Management in Australia: International Implications. Land 2020, 9, 234. [CrossRef]

54. Pannell, D.J.; Ridley, A.; Regan, P.; Gale, G. CRC for Plant-Based Management of Dryland Salinity. Available online: https: //www.yumpu.com/en/document/read/33385017/focus-on-salt-crc-leme (accessed on 31 October 2020).

55. Catchment Management-Setting the Scene. An Overview of Catchment Management Models in Australia. Went Worth Group of Concerned Scientists, Canberra. Available online: https://wentworthgroup.org/wp-content/uploads/2014/01/WilliamsCatchment-Management.pdf (accessed on 15 September 2020).

56. Leake, J.E.; Morison, J. Land Repair Fund: A model for exploiting the nexus between land repair, improved production, and profit. Aust. Agribus. Rev. 2008, 16, 1-22.

57. Lal, R. Carbon sequestration into saline soils. J. Soil Salin. Water Qual. 2009, 1, 30-40.

58. Tucker, W. Debunking: 8 Myths about Carbon Offsetting. In Ecosystem Market Place; 2020; Available online: https://www. ecosystem-marketplace.com/articles/debunked-eight-myths-carbon-offsetting/ (accessed on 10 November 2020).

59. Petrokofsky, G.; Kanamaru, H.; Achard, F.; Goetz, S.; Joosten, H.; Holmgren, P.; Lehtonen, A.; Menton, M.C.S.; Pullin, A.S.; Wattenbach, M. Comparison of methods for measuring and assessing carbon stocks and carbon stock changes in terrestrial carbon pools; do the accuracy and precision of current methods compare? A systematic protocol. J. Environ. Evid. 2012, 1, 6. [CrossRef]

60. Issa, S.; Dahy, B.; Ksiksi, T.; Saleous, N. A review of Terrestrial Carbon Assessment Methods using Geo-Spatial Technologies with Emphasis on Arid lands. Remote. Sens. 2020, 12, 2008. [CrossRef]

61. Qiu, H.; Su, L.; Feng, X.; Tang, J. Role of Monitoring in environmental regulation: An empirical analysis of grazing restrictions in China. Environ. Sci. Policy 2020, 114, 295-304. [CrossRef]

62. Ventura, Y.; Eshal, A.; Pasternak, D.; Sagi, M. The Development of Halophyte-Based Agriculture: Past and Present. Annu. Bot. 2015, 115, 529-540. [CrossRef] [PubMed]

63. Buhmann, A.K.; Waller, U.; Wecker, B.; Papenbrock, J. Optimisation of culturing conditions and selection of species for the use of halophytes as bio filters for nutrient-rich saline water. Agric. Water Manag. 2015, 149, 102-114. [CrossRef]

64. Robertson, S.M.; Lyra, D.A.; Mateo-Sagasta, J.; Ismail, S.; Akhtar, M.J.U. Financial Analysis of Halophyte Cultivation in a desert Environment using Different Saline Water Resources for Irrigation. In Ecophysiology, Abiotic Distress Responses and Utilisation of Halophytes; Hasanuzzaman, M., Nahar, K., Öztürk, M., Eds.; Springer Nature Pte Ltd.: Singapore, 2019. [CrossRef]

65. Marcum, K.B.; Yensen, N.P.; Leake, J.E. Genotypic variation in salinity tolerance of Distichlis spicata turf ecotypes. Aust. J. Exp. Agric. 2007, 47, 1506-1511.

66. Toze, S. Reuse of effluent water-benefits and risks. New Directions for a diverse planet. In Proceedings of the 4th Inter-national Crop Science Congress Sept CSIRO, Brisbane, Australia, 26 September-1 October 2004.

67. Barrow, C.J. Biochar: Potential for countering land degeneration and for improving agriculture. Appl. Geogr. 2012, 34, 21-28. [CrossRef]

68. Panta, S.; Flowers, T.; Lane, P.; Doyle, R.; Haros, G.; Shabala, S. Halophyte Agriculture: Success Stories. Environ. Exp. Bot. 2014, 107, 71-83. [CrossRef]

69. Tedesco, M.; Scalici, C.; Vaccari, D.; Cipollina, A.; Tamburini, A.; Micale, G. Performance of the first Reverse Electrodialysis pilot plant for power production from saline waters and concentrated brines. J. Membr. Sci. 2016, 500, 33-45. [CrossRef]

70. Akinshina, N.; Azizov, A.; Karasyova, T.; Klose, E. On the issue of Halophytes as energy plants in saline environments. Biomass Energy 2016, 91, 306-311. [CrossRef]

71. Gunning, D.; Maguire, J.; Burnell, G. The development of sustainable Saltwater-based Food Production Systems: A review of Established and Novel Concepts. Water 2016, 8, 598. [CrossRef]

72. Bresdin, C.; Glenn, E.P. Distichlis palmeri: Perennial Grain Yields under Saline Paddy-style Cultivation of Grains on Seawater. J. Agric. Environ. Sci. 2016, 5, 1-7. [CrossRef]

73. Haros, G.; Leake, J.E. Are the Outcomes that are Vital for the Survival of Mankind Achievable in an Era of GlobalWarming. In $A$ Better World; Tudor Rose for the High-Level Political Forum; UNCCD: Bonn, Germany, 2018; Volume 4, ISBN 978-0-9956487-5-3710.

74. World Bank. Community Driven Development. Available online: https://www.worldbank.org/en/topic/communitydrivendevelopment (accessed on 25 January 2019).

75. Leake, J. The Mixed Results of Development Aid. Chapter 2.2 in Aspects of Participatory Planning with Opium Growers in Vietnam. Master's Thesis, University of Melbourne, Melbourne, Australia, December 2000.

76. UNCCD. \$14 b Commitment to The Great Green Wall Project Announced 13 January 2021. Available online: https://www. unenvironment.org/news-and-stories/story/good-news-africas-great-green-wall (accessed on 17 January 2021).

77. Global Environment Facility. Available online: https://www.thegef.org/our-work (accessed on 2 February 2021).

78. Forest People's Organization. Available online: http:/ /www.forestpeoples.org/en/about (accessed on 25 January 2019). 
79. Greenhouse Gas Market Quarterly Report; IETA Insights no 4, Nov. 2018. Available online: https:/ / www.ieta.org/resources / Resources/GHG_Report/2018/IETA\%20Insights\%20Q4_2018.pdf (accessed on 25 January 2020).

80. Glenn, E.; Squires, V.; Brown, J. Saline soils in drylands: Extent of the problem and prospects for utilization. In World Atlas of Desertification; Middleton, N., Arnold, T.E., Eds.; John Wiley \& Sons: Hoboken, NJ, USA, 1992; pp. $144-148$.

81. White, H.; Menon, R.; Waddington, H. Community-Driven Development: Does It Build Social Cohesion or Infrastructure? A MixedMethod Evidence Synthesis; Working Paper no 30; International Initiative for Impact Evaluation: Washington, DC, USA, 2018.

82. Bawden, R. Ecosystems Services: A Commentary. Land 2021, 10. in press. 